\title{
The Influence of Formal Authority and Delegator Teaching Style on Students' Enjoyment In The Business Studies Subject
}

La influencia de la autoridad formal y el estilo de enseñanza del delegado en el disfrute de los estudiantes en la asignatura de estudios empresariales

\author{
Abd Aziz Abd Samad ${ }^{* *}$ \\ Universiti Kebangsaan Malaysia - Malaysia \\ p92423@siswa.ukm.edu.my \\ Nor Aishah Buang* \\ Universiti Kebangsaan Malaysia - Malaysia \\ norais@ukm.edu.my \\ Asmar Yulasri \\ Universitas Negeri Padang - Indonesia \\ a.yulasri@yahoo.co.id \\ Ernawati \\ Universitas Negeri Padang - Indonesia \\ ernaftunp@yahoo.co.id
}

\begin{abstract}
The purpose of this study was to examine the teacher's teaching style and students' attitude towards the business studies subject. The samples were 189 upper six students who took business studies subject. This study used the survey method. Descriptive and inferential statistics used were Pearson correlations. The study found that the personal model teaching style was the preferred teaching style. Students' attitude towards the business studies subject was at a moderate level. Correlation analysis revealed a significant positive relationship between teachers' teaching style and students' attitude toward business studies subject. The results of Pearson's correlation test found that two types of teaching styles that were formal authority and delegator style had a significant relationship with the sub-constructs of attitude namely enjoyment.
\end{abstract}

Keywords: Teacher's Teaching Style, Students' Attitude, business studies subject, Grasha’s model, Gogolin and Swartz model.

\section{RESUMEN}

El propósito de este estudio fue examinar el estilo de enseñanza del maestro y la actitud de los estudiantes hacia la asignatura de estudios de negocios. Las muestras fueron 189 estudiantes de los seis primeros que tomaron asignaturas de estudios empresariales. Este estudio utilizó el método de encuesta. Las estadísticas descriptivas e inferenciales utilizadas fueron las correlaciones de Pearson. El estudio encontró que el estilo de enseńanza modelo personal era el estilo de enseńanza preferido. La actitud de los estudiantes hacia la asignatura de estudios empresariales fue moderada. El análisis de correlación reveló una relación positiva significativa entre el estilo de enseñanza de los maestros y la actitud de los estudiantes hacia la asignatura de estudios empresariales. Los resultados de la prueba de correlación de Pearson encontraron que dos tipos de estilos de enseńanza que eran autoridad formal y estilo delegador tenían una relación significativa con las subconstrucciones de actitud, a saber, el disfrute.

Palabras clave: Estilo de enseńanza del profesor, Actitud de los alumnos, asignatura de estudios empresariales, modelo de Grasha, modelo de Gogolin y Swartz.

\footnotetext{
${ }^{*}$ Corresponding author. Nor Aishah Buang, Faculty of Education, Universiti Kebangsaan Malaysia, 43600 Bangi, Selangor, Malaysia

** Universiti Kebangsaan Malaysia
}

Recibido: 22/09/2019 Aceptado: 01/11/2019 


\section{INTRODUCTION}

The business studies syllabus was designed in 1998 to enable students to understand and appreciate the three sub-areas that were business, management and entrepreneurship, which were considered to be the key components (Majlis Peperiksaan Malaysia 1998). In line with this development, Nor Aishah (2013) stated that business education was intended to provide students with a real-life form of education so that they could become proficient in understanding the nature of the economy besides providing alternative job skills as a potential entrepreneur. However, based on the STPM exam results analysis report for business studies subject from 2013 to 2017, it was found that the students who were fully passed showed inconsistent trends with increasing and decreasing percentages during those years. In 2013, the percentage of fully passed candidate in business studies subject was $83.87 \%$ compared to $82.54 \%$ in 2014 . This indicated a $1.33 \%$ decrease. Meanwhile, in 2015 and 2016 , there was a $1.23 \%$ and $1.80 \%$ increase of $83.77 \%$ and $85.57 \%$ of the candidates fully passed in both years. However, in 2017, the percentage of fully passed candidates for this subject was $80.78 \%$ which was a significant decrease of 4.79\% (Majlis Peperiksaan Malaysia 2013-2017). Therefore, the researcher was of the view that this inconsistent trend was related to the students' attitude towards the subject. In addition, researchers argued that although there were many factors contributing to this problem, one of them were the incompatibility between teachers' teaching style and students' learning style. This inconsistency was due to the teaching style used by the teachers that made the students lost interest, which ultimately influenced the attitude of the student and the level of achievement in the subject. This phenomenon, supported by Ford \& Chen (2001) and Richardson \& Tring (1997) in their study, found that the use of different teaching styles could influence students' achievement and attitude according to the level of teaching and student academic achievement. According to Abd Rahim (2005), one of the reasons for the decline in students' achievement was that many teachers take it easy and teach without demonstrating their professional expertise, especially in terms of teaching efficiency and failure to apply learning psychology knowledge to create a stimulating learning environment to enhance students' achievement. Abd Rahim' statement was supported by the study of Abd Majid (2002) who found that the teachers' teaching styles and practices were still teacher-centred. This teaching style still used the facts and content delivery as well as lacked of the practice of inquiry, constructivism, mastery, contextual and other teaching approaches that engage students in learning.

Such a scenario was because teachers were unable to apply what they learned at the university and teaching colleges in their teaching context. The failure of teachers to value individual differences, student-centred teaching and integrated teaching strategies were some of the causes of lack of interest in their teaching style. In addition, teachers were well-versed in the psychology of learning at university and teaching colleges that still prioritize teachers' knowledge of individual differences. Similarly, in the field of pedagogical knowledge, teachers had learned a number of teaching strategies and modules that could capture the interests, attitudes, needs, and individual differences of students. However, there were some teachers who were still unable to demonstrate effective teaching style. Researchers acknowledged that teachers often faced a variety of problems in creating a learning environment that improved students' achievement. Teachers often faced classroom situations that were less conducive, small and packed. In addition, there were too many students in a classroom. This classroom environment made it difficult for teachers to apply the concepts of individual differences, student-centred teaching and integrated teaching strategies. As a result, there were a number of teachers who might turn back to the use of lectures which was a teacher-centred teaching style, from student-centred teaching strategies that ultimately impact student interest, attitude and academic achievement. Based on these issues, the question was whether there were any proactive efforts by the Ministry of Education in improving the image of the teaching profession? Were there any courses or programs related to the teaching style in order to provide exposure for teachers in schools? Why they were lack of modules related to the teaching style published by university lecturers in the form of books, journals, or magazines in each school to serve as a guide for teachers to strengthen their teaching style in schools? Why these modules were available only in universities and teacher colleges?. In particular this study attempted to answer the following questions:

1. What kind of teaching style for business studies that the student most interested in?

2. What is the level of students' attitude towards the subject of business studies?

3. Is there a significant relationship between the teaching style and the students' attitude towards the business studies subject?

4. Is there a significant relationship between the teaching style and students' sub-construct of attitude the towards the business studies subject?

\section{LITERATURE RIVIEW}

The study of Dressel and Marcus (1982) and Woods (1994) found that the discipline-centred and teacher-centred style of teaching caused students to passively accept teaching materials as they have to accept the modules and teaching materials used by the teachers. Meanwhile, only student-centred teaching style would keep students engaged in learning activities. According to John Lackey (1996) lecture method was a reflection of teacher- centred style and a passive example to students while student-centred style, instruction was more focused on the student and the cognitive development of a student. The goal of the teacher was to help students understand knowledge formation as a process rather than a product. Grasha's (1996) study on 761 college classrooms involved in various fields of study. The teaching style was categorized into four groups. Thus, Grasha found that the most dominant teaching style used among the teachers in the college was group 1 (expert / formal) 38\%, group 2 (personal / expert / formal) 22\%, group 3 (facilitator / personal / expert) $17 \%$ and group 4 (delegator / facilitator / expert) 15\%. According to Grasha, teaching styles created a classroom atmosphere. For example cluster 1 (expert / formal) indicated that teachers were trying to create a fresh and modern classroom environment. Felder \& Henriques's (1995) study showed that incompatible teaching style with students' learning style could significantly affect student learning, attitude, behaviour, and motivation. According to Felder \& Henriques, incompatible teaching style with student learning style would cause students to become bored and likely to become frustrated and quit their learning activities. Their research was supported by the study of Hyland (1993). In addition, a study by Roslind (2003) on 260 
Form 2 and Form 5 students at a secondary school in Seri Aman district, Sarawak found that teachers had used all five Grasha's teaching styles model in Malay Language teaching. Three dominant teaching styles used by teachers had been identified namely formal authority style, personal model style and facilitator style. The most dominant style between the three teaching styles was the personal model teaching style. Roslind's statement was in line with the results of Nasir's (2006) study of 180 students from six schools in the district of Semporna, Sabah, which found that there was a significant relationship between all teaching styles and students' attitude towards history subject. Student attitude towards teachers' teaching style based on grade achievement of history in PMR found that only the formal authority teaching style was significant while personal and facilitator style model were not significant. His research analysis found that personal model teaching style was the dominant teaching style. However, a study by Siti Zubaidah (2006) on 120 Form Four Science students in Sepang district showed that students preferred teachers to use facilitator teaching style than other teaching styles.

Students' attitude toward a subject especially science according to Gogolin and Swartz (1992) was measured from six aspects: perceptions towards the teacher, concern on science, the importance of science to the society, selfconcept in science, enjoyment of science and motivation for science. Whereas students' attitude towards business education according to Donald et al. (n. d.) was influenced by the classroom environment, whether it was through the use of business textbooks, teachers' exposure to business, lectures on business opportunities held in schools or students' exposure to practical training related to business. The results of the study of John et al. (2008) of 441 university students comprising 244 business studies respondents and 197 non-business studies respondents found that education pedagogy of business studies had an impact on students' attitudes and personalities especially in making decisions. Business students were found to be less ethical such as selfish and deceptive in the decision-making process compared to students who were not in business. Nor Aishah \& Affzalina (2017) did a study on 308 final year undergraduate degree students from several Public Universities in Selangor who were taking Science courses. The purpose of ths study was to identify the level and relationship of entrepreneurial attitudes, entrepreneurial thinking and entrepreneurial behavior with the level of business planning. The results showed that the level of entrepreneurial attitude, thinking, and behaviour towards the level of business planning among students was at a moderate level. The correlation analysis showed that there was a significant, positive but weak relationship between entrepreneurial attitudes, thinking and behavior with the level of business planning. The implications of this study were to help education administrators innovate and transform the business and entrepreneurial education curriculum especially in the higher eduction institutions to better cultivate a high level of entrepreneurial characteristic among students.

\section{METHODOLOGY}

This was a survey study. Data were collected using a set of research tools containing a set of questionnaires. The questionnaire consisted of three sections: (i) biodata, (ii) teachers' teaching style, (iii) students' attitude towards business studies. There were 189 upper six students in seven secondary schools in Johor Bahru district. All of them were students who would be taking the Malaysian Higher School Certificate (STPM) examination and taking the business studies subject. Statistical data were analysed using descriptive and inferential methods. Descriptive statistics used were the mean value to determine the style of teaching that the students most interested and the level of students' attitude towards the business studies subject. The inferential statistics used were Pearson's correlation, to test the correlation between teachers' teaching style and students' attitude towards business studies subject.

\section{RESEARCH TOOL}

A set of questionnaires was used to obtain the biodata, teachers teaching style and students' attitude towards business studies. The questionnaire measuring teachers' teaching style was translated through the method of 'translate and re-translate' from the original questionnaire developed by Grasha (1996). The questionnaire consisted of 40 items constructed on a 5-point Likert scale. These items measured the subjects' behaviour that reflected the teachers' preferred teaching style. The reliability coefficient (Alpha Cronbach) of this questionnaire was 0.81 . To measure students' attitude toward business education, researchers had used questionnaires developed by Gogolin \& Swartz (1992). The questionnaire was translated using the 'translate and re-translate method' and had 40 items constructed on a 5-point Likert scale. These items measure students' attitudes toward the subject of business studies. The reliability of this questionnaire was 0.76 .

\section{THE PILOT STUDY}

A pilot study was conducted on 30 upper six students who would sit for the STPM exam and took business studies subject. These students had a background similar to the study subject. The purpose of this pilot study was to obtain the reliability of the two research tools used, which were teachers' teaching style and students attitude towards the business studies subject.

\section{RESULT}

A total of 189 students participated in the survey. Of these, 54 were male and 135 were female students. There were 130 Malay students, 38 Chinese and 21 Indian students. In addition, out of the 189 students, 88 had business experience and 101 students had no business experience. The students were divided according to the teachers' teaching style and the students' attitude towards business studies of their choice. For the purpose of analysis, the teaching style had been divided into five styles namely expert, formal authority, personal, facilitator and delegator style. Meanwhile, students' attitudes had been divided into 6 constructs namely perceptions towards the teacher, anxiety, importance to the society, self-concept, enjoyment and motivation. 
Table 1: Mean score of teaching style which the students were interested

\begin{tabular}{lccc}
\hline \multicolumn{1}{c}{ Teaching style } & N & Mean & Standard deviation \\
\hline Expert style & 189 & 3.9358 & 0.45649 \\
Formal Authority Style & 189 & 3.5489 & 0.61122 \\
Personal Model Style & 189 & 4.0390 & 0.48980 \\
Facilitator Style & 189 & 3.9716 & 0.53168 \\
Delegator Style & 189 & 3.7169 & 0.54736 \\
\hline
\end{tabular}

Table 1 showed the type of teaching style that business student most interested in were personal model, followed by facilitator style and expert style. While the delegator style and the formal authority style were the teaching styles the students were less interested.

Table 2: Mean scores of students' attitude towards business studies subject.

\begin{tabular}{lcccc}
\hline Students' attitude & N & Mean & $\begin{array}{c}\text { Standard } \\
\text { Deviation }\end{array}$ & $\begin{array}{c}\text { Level of } \\
\text { attitude }\end{array}$ \\
\hline $\begin{array}{l}\text { Attitude towards business } \\
\text { studies }\end{array}$ & 189 & 3.0920 & 0.22479 & $\begin{array}{c}\text { Moderately } \\
\text { positive }\end{array}$ \\
\hline
\end{tabular}

Table 2 showed that the students' overall attitude towards the business studies subject was moderately positive.

Table 3: The correlation analysis of the relationship between teachers' teaching style that the students were interested and students' attitude towards business studies subject.

\begin{tabular}{lcccc}
\hline & $\mathbf{N}$ & $\mathbf{r}$ & $\mathbf{r}^{\mathbf{2}}$ & Significance \\
\hline $\begin{array}{l}\text { Teachers' Teaching Style that the } \\
\text { Students were Interested and Students' } \\
\begin{array}{l}\text { Attitude towards Business Studies } \\
\text { Subject }\end{array}\end{array}$ & 189 & 0.346 & 0.12 & $0.000^{* *}$ \\
\hline
\end{tabular}

** Significant at the level of $\mathrm{k}<0.01$ (two-tailed)

Table 3 showed the significant relationship between the teachers' teaching style and the students' attitude towards the business studies subject. Pearson's correlation analysis found a low correlation between teachers' teaching style and students' attitude towards business studies subject. This low $r$ value indicated that the relationship strength of the two variables was low but their relationship was acceptable.

Table 4: Correlation analysis of the relationship between teachers' teaching style that students were interested and the sub-construct of students' attitudes towards the business studies subject.

\begin{tabular}{llllll}
\hline $\begin{array}{l}\text { Teachers' Teaching } \\
\text { Style }\end{array}$ & Expert Style & $\begin{array}{l}\text { Formal } \\
\text { Authority Style }\end{array}$ & $\begin{array}{l}\text { Personal } \\
\text { Model Style }\end{array}$ & Facilitator Style & $\begin{array}{l}\text { Delegator } \\
\text { Style }\end{array}$ \\
\hline $\begin{array}{l}\text { Attitude Sub-Construct Perception towards the teachers } \\
\mathbf{r}\end{array}$ & 0.281 & 0.142 & 0.247 & 0.234 & 0.199 \\
Sig. & $0.000^{* *}$ & 0.052 & $0.001^{* *}$ & $0.001^{* *}$ & $0.006^{* *}$ \\
Anxiety & & & & & \\
$\mathbf{r}$ & -0.069 & -0.002 & -0.190 & -0.190 & 0.370 \\
Sig. & 0.344 & 0.976 & 0.800 & 0.795 & 0.616 \\
Importance to the society & & & & \\
$\mathbf{r}$ & 0.212 & 0.189 & 0.313 & 0.232 & 0.246 \\
Sig. & $0.003^{* *}$ & $0.009^{* *}$ & $0.000^{* *}$ & $0.001^{* *}$ & $0.001^{* *}$ \\
Self-concept & & & & & \\
$\mathbf{r}$ & -0.330 & -0.360 & 0.007 & 0.290 & -0.007 \\
Sig. & 0.651 & 0.622 & 0.923 & 0.690 & 0.923 \\
Enjoyment & & & & & \\
$\mathbf{r}$ & 0.143 & 0.221 & 0.122 & 0.159 & 0.277 \\
Sig. & 0.050 & $0.002^{* *}$ & 0.095 & 0.029 & $0.000^{* *}$ \\
Motivation & & & & & \\
$\mathbf{r}$ & 0.255 & 0.331 & 0.213 & 0.197 & 0.291 \\
Sig. & $0.000^{* *}$ & $0.000^{* *}$ & $0.003^{* *}$ & $0.007^{* *}$ & $0.000^{* *}$ \\
\hline
\end{tabular}

** Significant at the level of $\mathrm{k}<0.01$ (two-tailed)

Table 4 showed that there was a significant relationship between the teaching style of teachers and the sub-constructs of students' attitudes towards the business studies subject. The results showed that two types of teachers' teaching style - formal authority style and delegator style had a significant relationship with the significant level of $\mathrm{p}<0.01$ with the 
sub-constructs of attitude which was enjoyment.

\section{DISCUSSION}

Based on the results, it was found that interest in the teaching style played a significant role in shaping and influencing students' attitude towards a given subject. The study also found that students were more interested in the studentcentred teaching style than teacher-centred. Therefore, teacher needed to have a teaching style that suits the needs and abilities of the students in the classroom to help them received the delivered lessons effectively. The results of the statistical analysis showed that the teaching style of business teacher that the students were most interested in was the personal model. The results of this study were similar to those of Roslind (2003) and Nasir (2006). Thus, referring to Grasha's (1996) teaching style model, the researchers concluded that students were interested in the personal model teaching style because the teacher played the role as a model or approach for students to follow during the teaching and learning process. In addition, the role of the teacher as a mentor required the student to make direct observations and to follow every approach or method the teacher had introduced in order to provide insight and improve the quality of students' achievement. In addition, the teacher always played a role in teaching students how and what students needed to do to master a certain topic. Attentive and friendly teachers shared their experiences by providing illustrations and examples to enable students to adapt to the realities of their daily lives.

In addition, the results of the statistical analysis showed that students' attitude towards business studies subject was at a moderate level. This was because five out of the six sub-constructs of attitude that were perceptions towards the teacher, anxiety, self-concept, enjoyment and motivation; student expression of business education showed that at least 35\% of respondents did not receive positive feedback. The findings of this study were in line with the findings of Norhatta (2003) which showed that the level of knowledge, skills and attitudes in business and entrepreneurship was moderate among students.

Similarly, the findings showed that there was a significant relationship between teachers' teaching style and students' attitude towards business studies subject. However, Pearson's correlation analysis showed low correlation. Referring to Grasha's (1996) teaching style model, researchers concluded that the relationship between teachers' teaching style and students' attitude influenced one another. This was because teachers were intermediaries of teaching and learning factors such as teaching and learning environment, content, student conditions, school system, students socio-culture and so on. These factors slightly influence the teaching style that the teachers wanted to apply to students. These scenarios gave teachers an opportunity to explore the needs of students in their learning activities. The ability of teachers to take into accounts various factors in creating an effective teaching and learning environment would ultimately influence students' attitude towards the subject. In addition, referring to Gogolin and Swartz's (1992) model, researchers found that students' attitude was influenced by a number of factors that shape that attitude whether it was positive or negative in the course of action. Therefore, the teachers should play a role in shaping students' positive attitudes through their roles as advisors, knowledgeable individuals, lecturers, assessors, discussion leaders, and counsellors. These roles form the basis of the interaction between teachers' teaching and students' learning that would create compatibility or incompatibility in the learning activities that ultimately leads to the development of a more positive student attitude. The researcher thought that the teaching style of teachers could be attributed to the opinion of Peacock (2000) who showed that the teaching style and the compatible learning style made students more confident and trusting the teachers and could develop a more positive attitude. It was acknowledged by Felder \& Henriques (1995), Hersey et al. (1992), Hyland (1993), and Tudor (1996) that showed that teachers' teaching style was related to students' attitudes, behaviours and motivations.

In addition, Pearson's correlation analysis revealed the existence of a significant relationship between teacher teaching style and sub-constructs of attitude toward the business studies subject. The findings showed that two types of teachers' teaching styles, formal authority and delegator styles had a significant relationship with the significant level of $\mathrm{p}<0.01$ with the sub-constructs of attitude which was enjoyment. According to Grasha (1996), formal authority teachers thought that teaching should be in the standard forms that included the teaching goals set by the school, the expectations and rules of student behaviour as reflected in the school rules. The teachers with this teaching style were structured, rigid and less flexible in the teaching and learning process. In addition, this formal authority style restricted students' critical and creative thinking because teachers considered their way was the best. However according to Noriah et al. (1999) the formal authority style had always been restricted by rules and laws that emphasized creativity. When teachers were creative in their teaching, students would enjoy and be interested in the knowledge presented. This was acknowledged by Grasha (1996) and Roslind (2003) in their study which showed that formal authority styles were among the most commonly used teaching style among college and school teachers. According to Grasha (1996), this teaching style was practiced because the teachers tried to create a fresh and modern classroom environment. Meanwhile, teachers with delegator style paid attention to students' ability to function autonomously. Students are encouraged to carry out their assignments individually or in groups. The presence of teachers was only as a source of reference that would provide help or guidance when the students requested them. In addition, teachers with this style helped students to feet like they were independent learners (Grasha 1996). For example, after the teacher presented a topic, the student would conduct a group discussion, and then the student would do a presentation to present the findings to the whole class using ICT materials. Therefore, students would enjoy having the autonomy to carry out a learning activity that fitted into the 21st century learning activities. According to Nor Aishah (2018), in business and entrepreneurship education, a learning approach that promoted adventure, exploration and continuous search among students was the appropriate and effective way of educating students to understand, appreciate and pursue careers in that field. Indirectly, this would shape students' self-esteem, self-confidence and high leadership potential. Therefore, researchers believed that teaching 
styles (formal authority / delegator) should be practiced by teachers in creating a creative and enjoyable atmosphere of teaching and learning according to the 21 st Century Learning.

\section{CONCLUSION}

Based on the discussion and the summary of the results, it was clear that the students' interest in the teachers' teaching style played an important role in shaping and influencing students' attitude towards a given subject. The study also found that students were more interested in the use of a more student-centred teaching style than the teacher-centred. Therefore, a teacher needed to have a teaching style that suits the needs and abilities of the students in the classroom so that they could enjoy engaging in a variety of learning activities. At the same time, it helped students to easily master the knowledge that the teachers conveyed.

\section{ACKNOWLEDGEMENT}

This research was supported by the grant from the Faculty of Education, Universiti Kebangsaan Malaysia (GIP-2018003).

\section{BIBLIOGRAPHIC REFERENCES}

Abd. Majid Mohd Isa. 2002. Pemikiran dalam pendidikan. Kota Kinabalu : Universiti Malaysia Sabah.

Abd. Rahim Abd. Rashid. 2005. Profesionalisme Keguruan: Prospek dan Cabaran. Kuala Lumpur: Dewan Bahasa dan Pustaka.

Donald L.B, Marjorie M.G \& Conrad E.A. t.th. Improving Student Attitudes Toward Careers In Small Business. http://www.sbaer. uca.edu/research/sbida/1985/PDF/39.pdf

Dressel, P.L. and Marcus, D. 1982. Education as a humanizing experience. In P.L. Dressel and D. Marcus (Eds) On teaching and learning in college: Reemphasizing the roles of learners and the disciplines, hlm. 32-65. San Francisco: Jossey-Bass Publishers.

Felder, R.M \& Henriques, E.R. 1995. Learning and teaching styles in foreign and second language education. Foreign Language Annals. 28 (1): 21-31

Ford, N \& Chen, S.Y. 2001. Matching/mismatching revisited: An empirical study of learning and teaching styles. British Journal of Educational Technolog. 32(1): 5-22.

Gogolin, L. \& Swartz, F. 1992. A quantitative and qualitative inquiry into the attitude toward science of non science college students. Journal of Research In Science Theaching 29 (5) : 487-504.

Grasha, A.F. 1996. Teaching with style. A practical guide to enhance learning by understanding learning and teaching style. New York: Alliance Publisher.

Hersey, P., Blanchard, K.H \& Caracushansky,s. 1992. Variations in the teaching style on course outcomes. Management of organizational behavior. Utilizing human resources. Eaglewood Cliff, N. Jersey: Prentice Hall.

Hyland, K. 1993. Culture and learning: A study of the learning styles preferences of Japanese students. RELC Journal. 24 (2): 69-91

John A.S, Todd A.B, Levente L,Alberta C.S \& Brennen B. 2008. Attitude and Divergence in Business Students:An Examination of Personality Differences in Business and Non-Business Students. Electronic Journal of Business Ethics and Organization Studies 13 (2): 70-78.

John L. 1996. Faculty Manual. A Guide for Bible School Teaching http://www.apeo.org/schools/Faculty\%20Manual.Pdf

Majlis Peperiksaan Malaysia. 1998. Pengajian Perniagaan : Sukatan Pelajaran Dan Soalan Contoh. Selangor Darul Ehsan: Percetakan Warni Sdn. Bhd.

Majlis Peperiksaan Malaysia. 2013 - 2017. Laporan tahunan. Selangor: Affluent Master.

Nasir Kirino. 2006. Hubungan antara Gaya Pengajaran Guru dengan Sikap Pelajar terhadap Mata Pelajaran Sejarah. Projek Penyelidikan Sarjana. Fakulti Pendidikan. Universiti Kebangsaan Malaysia.

Nor Aishah Buang \& Affzalina Hassan. 2017. Perbandingan Tahap Sikap, Pemikiran Dan Tingkah Laku Keusahawanan Dengan Tahap Perancangan Berniaga Mahasiswa Jurusan Sains. Journal of Global Business and Social Entrepreneurship (GBSE): 86-99.

Nor Aishah Buang. 1998. Tujahan pendidikan teknik dan vokasional keusahawanan. A Workshop Report on Research Focus of the National Universiti Kebangsaan Malaysia, pages 26-31.

Nor Aishah Buang. 2013. Pendidikan Keusahawanan. Publisher: Universiti Kebangsaan Malaysia.

Nor Aishah Buang. 2018. Cabaran Membangun Usahawan Siswazah. Publisher: Dewan Bahasa dan. Pustaka, Kuala Lumpur.

Norhatta Mohd. 2003. Pengetahuan, kemahiran dan sikap dalam perniagaan dan keusahawanan dikalangan pelajar-pelajar sekolah menengah di sekitar Lembah Klang. Unpublished Masters Thesis. Fakulti Pendidikan. Universiti Kebangsaan Malaysia.

Noriah Mohd Ishak, Nor Sakinah Mohamed, Noor Kefli Mohd. Sulong, Prof. Madya Datin Dr. Amla Mohd. Salleh. 1999. Gaya Pertautan, Gaya Pengajaran dan Komitmen terhadap Profesyen Perguruan Di Kalangan Guru-Guru Pelatih UKM. Laporan Projek G/4/99. Bangi: UKM.

Peacock, M. 2000. Learning style and teaching style preferences in EFL. Hong Kong Journals Online. 12 : 88-114. http://www.sunzi1. lib.hku.hk/hkjo/view/10/1000206.pdf

Richardson, T.R \& Tring, J.P. 1997. Student characteristics and learning or grade orientation influence preferred teaching style. College Teaching Journal 31(3): 347-350

Roslind Anak Mawing. 2003. Hubungan antara Gaya Pengajaran Guru dengan Sikap Pelajar terhadap Bahasa Melayu. Projek Penyelidikan Sarjana. Fakulti Pendidikan. Universiti Kebangsaan Malaysia.

Siti Zubaidah Bte Mohamed Said. 2006. Gaya pengajaran guru yang disukai dengan sikap pelajar terhadap mata pelajaran biologi. Projek Penyelidikan Sarjana. Fakulti Pendidikan. Universiti Kebangsaan Malaysia.

Tudor, Ian. 1996. Learner-centeredness as language education. New York : Cambridge University Press.

Woods, D. R. 1994. Problem-based learning: How to gain the most from PBL. 2nd ed. Ontario Canada: Waterdown. 